\title{
Effects of Environment on Academic Performance of Students in Agricultural Science in Secondary Schools in Rivers State, Nigeria
}

\author{
EKEZIE, Anthony Imo A. (PhD) \\ Department of Vocational and Technology Education \\ Rivers State University \\ P. M. B. 5080, Port Harcourt \\ Nigeria
}

\begin{abstract}
The study which adopted descriptive survey design was carried out to determine the effects of the environment on academic performance of students in Agricultural Science in Secondary Schools in Rivers State, Nigeria, having noted the importance of Agriculture to the nation's economy. The study population and sample were 380 and 48 teachers respectively. Three research questions guided the study. Mean and Standard deviation were used to analyze the research questions. The findings of the study revealed among others that poor parental guidance, lack of motivation, poor training environment, lack of competent teachers, lack of pilot farms are some of the issues affecting the performance of students in Agricultural Science in secondary schools in Rivers State. From the findings, it was recommended among others that Government should provide adequate training facilities alongside the provision of pilot farms in all secondary schools in Rivers State to enhance students' academic achievements in Agricultural Science.
\end{abstract}

Keywords: Agricultural Science, academic performance, environment, school, home, student, teacher

\section{Introduction}

Agricultural Science is one of the science subjects offered in secondary schools in Nigeria with the aim of training the students in the knowledge and practice of Agriculture for massive food production for the overall economic growth and development of the nation. According to South African Qualification Authority(2003), Agricultural Science refers to the study of the relationship between soils, plants and animals in production and processing of food, raw materials, fuel and any other agricultural commodities that have an economic, aesthetic or cultural value. In the views of Oberleand Keeney (1990), Agricultural Science entails a complex and multidisciplinary field that represents an interconnection between human and natural environments. Agricultural Science can be seen as a science and art of plant and animal production to uplift the standard of living. Agricultural Science is a subject given birth to via Agricultural education. Agricultural education has been well-instituted in the Nigerian educational system some decades ago due to its vital roles in national development. Agricultural education as a branch of Vocational Technology Education aims at addressing the challenges of short supply of food and natural resources needed for human consumption and economic advancement of Nigeria due to inadequate trained personnel in Agricultural Science. According to Olaitan(1984), the incessant rise in population experienced by many developing countries including Nigeria results in acute food shortages irrespective of the numerous agricultural resources available in such countries. The central Governments in most African countries having observed the menace of short supply of food in their domains quickly swift into action by embarking on Agricultural education programmers in their educational institutions for the purpose of solving the problem. Agricultural education gives specific educational instructions on crop production, animal husbandry, soil science, water conservation, agricultural mechanization and related areas of specializations in agriculture for maximum productivity (Olamie, 2012). In the words of Wright(2012), the major goal of Agricultural education is to prepare youths and adults for different career paths in Agriculture. Prior to the discovery of oil/gas in Oloibiri, Bayelsa State in South-South, Nigeria in 1956, agriculture has been the mainstay of the nation's foreign earnings and Gross Domestic Product (GDP). Agricultural Science in secondary schools as at that time was seen as one of the most important science subjects that engaged students in practical training in Agro-based areas such as farming, fishing, animal husbandry, among others together with the theoretical instructions delivered in the classrooms thereby making them productive members of the society (Directorate of Employment, 2008). Similarly, in our contemporary society, agriculture is seen as a vital key for human existence as most of the food and material items used on a daily basis are made possible by it. According to the Federal Ministry of Education (2004), agricultural science education has a very long history in Nigeria directed towards the development of the nation. 
Although agricultural science as a subject offered in secondary schools in Nigeria as featured in the educational curriculum serves a noble course, the academic achievements of students in the subject is observed to be very poor.

According to Ekezie and Owo (2019), the performances of Agricultural Science students in Nigerian secondary schools today are observed to be extremely very poor in terms of practical skills acquisition in agricultural education practices. Ekezie and Owo stressed further that this trend is evident in the students' nonchalant and lackadaisical attitudes towards farming, fishing, and other agro-based occupations. In the views of Esiobu (2005), Agricultural education experts revealed that secondary school students of this present era do not show any atom of interest in Agricultural Science. Several factors may be responsible for students' lack of interest in Agriculture. One of such factors that may be responsible to the poor performances of students in Agricultural Science in secondary schools in Nigeria today is the environment. The environment is one of the determining factors for effective teaching and learning. This is because the environment plays a very important role in the growth and development of every individual student. According to Arifin, Wahab, Teh, \&Otman(2018), a healthy environment creates a perfect individual, whereas an unhealthy environment leads to problematic society. Bad habits are formed based on what an individual learns or acquires from his/her immediate environment. The changes in behavior of the students is as a result of the fact that the individual student comes from a unique environment or setting and whatever happens in that environment is exactly what the fellow learns and practice at school. It is very necessary to state that no meaningful learning can be obtained from a poor home and learning (academic) environment. A conducive environment therefore, is what enhances the academic achievements of students.

A conducive learning atmosphere can serve as a powerful tool to modify or shape the behavioural learning processes of an individual (Aldridge, Mcchesney, \&Afari, 2017). Some of the problems facing the society today are as a result of poor environmental conditions in the home, the school and other social environments in which the students find themselves in. Both the home and school environments have tremendous influence on the academic achievements of students in secondary schools especially those that wants to major in Agricultural Science. For instance, a student who resides in a serene environment where noise is controlled will not want to come to school to cause distraction to other students through noise-making and bullying capable of disrupting academic activities because he must have been used to serene environmental condition of orderliness and peaceful co-existence. By implication, this category of students will strive to study hard both at home and in school so as to succeed in their educational pursuits. On the contrary, a student who comes from a poor environmental background where parents fight each other or where lawlessness thrives would also want to exhibit such traits at school. Such student may want to fight his or herpeers at schoolat any slightest provocation. Sometimes, deviant students may also want to insult teachers which in some cases, may attract some penalties and in the process of avoiding such disciplinary actions, they may opt for truancy.

Lack of interest in academic activities becomes the order of the day when students are not properly attended to due to poor environmental conditions at home and school which automatically have some adverse consequences ontheir academic achievements. According to Uzochi(2011), the poor performance of students in examinations is traceable to many factors within and outside the school. When students fail to learn effectively at home due to poor learning facilities such as reading desk, poor supply of electricity, unavailability of internet, computers and other information technology accessories that facilitate effective academic activities, they tend to avoid academic exercises resulting to poor performance at school. The performance of students in Agricultural Science in Rivers State may be due to negative environmental effects on students' education. Some major contributing factors to students' poor academic performance in Agricultural Science are poor classroom buildings, poor environmental condition of the home, poor teacher-students' relationship, poor reading culture, poor laboratories, poor libraries, misuse of technological facilities such as mobile phones, internet, computer, among others. These serious issue of environmental effects on academic performance of students in Agricultural Science in Rivers State was the rationale behind the researcher's quest to conduct this study.

According to Ekezie and Owo (2019), the academic performance of Agricultural Science students in Nigerian secondary schools today fall below average in terms of practical skills acquisition in agricultural practices and programmes. The colossal failure of senior secondary students in Science subjects such as Agricultural Science at external examinations in Nigeria's secondary educational institutions attracts the attention of curriculum designers, policy makers, implementers, and administrators and teachers of Agriculture in Nigeria. This critical issue of low academic performance of students due to their disinterest in Agriculture particularly calls for a serious concern considering the agricultural roles of providing food for the teeming population of Nigeria as well as provision of raw materials to the nations' industries for economic advancement. The environment which is one of the factors determining effective learning capable of yielding academic excellence needs to be critically looked into to ascertain effective teaching and learning of Agricultural Science in secondary schools in Rivers State, Nigeria. 
The objective of this study was to determine the effects of the environment on academic performance of students in Agricultural Science in Rivers State, Nigeria. To realize the study objective, three research questions were posed by the researcher to guide the study. The research questions were as follows: What are the home environmental issues affecting the academic performance of students in Agricultural Science in Secondary Schools in Rivers State, Nigeria?

What are the schools environmental issues affecting the academic performance of students in Agricultural Science in Secondary Schools in Rivers State, Nigeria?

What are possible ways of improving the performance of students in Agricultural Science in Secondary Schools in Rivers State, Nigeria?

\section{Materials and Methods}

The study adopted descriptive survey design. The study has a population of 380 senior secondary teachers in Andoni, Opobo/Nkoro and Okrika local government areas of Rivers State. Purposive sampling technique was used to obtain from the population, 48 Agricultural Science teachers which formed the study sample. Three research questions guided the study. The instrument for data collection was the researcher's self-structured 30- item questionnaire tiled "Environmental Effects on Students' Academic Performance Questionnaire (EESAPQ)". The EESAPQ was designed on Likert 5-point scale of strongly agree, agree, undecided, disagree and strongly disagree which yielded numerical values of 5, 4, 3, 2 and 1 respectively. Three experts in Agricultural education from Rivers State University, Port Harcourt face-validated the instrument. The reliability of the instrument was ascertained via Cronbach's Alpha method having yielded a reliability coefficient of 0.89 after showing consistent results in two intervals of administration. The instrument was distributed to respondents by the researcher and two other research assistants who also assisted in the retrieval of the duly filled questionnaire from the respondents. Mean and Standard deviation were descriptive statistical tools used to analyze the research questions. A criterion Mean of 3.00 formed the basis for decision making. This implies that items whose values range from 3.00 and above are accepted as effects of the environment on students' academic performance while those below the criterion mean value of 3.00 were rejected. Standard deviation values show homogeneity in the responses of the respondents.

\section{Results}

The results of the study were stated in line with the research questions as contained in the tables placed at the bottom of the text.

Research Question 1: What are the home environmental issues affecting the academic performance of students in Agricultural Science in Secondary Schools in Rivers State, Nigeria? Table 1 revealed that all the items are issues affecting academic performance of students in Agricultural Science with item 7 (4.15) and 3 (4.09) having the highest Mean value. this revealed that lack of subsistence training in fishing and farming as well as poor motivation are two major environmental factors contributing to poor students' performance in Agricultural Science. However, from the result as seen in table 1, item 9 whose Mean was (2.29) implied that increased criminal activity in the society does not affect the academic performance of students in Agricultural Sciences in Secondary Schools in Rivers State, Nigeria. Standard deviation values ranging from 0.48 to 1.04 indicate closeness in the responses of the respondents.

Research Question 2: What are the school environmental issues affecting the academic performance of students in Agricultural Science in Secondary Schools in Rivers State, Nigeria? Table 2 revealed that all items constitute school factors affecting the academic performance of students in agricultural science in secondary schools in Rivers state with the exception of items 9 (2.71) and 10 (2.88) respectively whose Mean values were below the criterion mean of 3.00. This result revealed that poor electricity and water supply in schools are not issues affecting students' academic performance in Agricultural Science in Secondary Schools in Rivers Stare, Nigeria. Standard deviation values ranging from 0.72 to 1.11 show homogeneity in the responses of the respondents.

Research Question 3: What are possible ways of improving the performance of students in Agricultural Science in Secondary Schools in Rivers State, Nigeria? Table 3 reveals that all the items constitute ways of improving the academic performances of students in Agricultural Science in secondary schools in Rivers State. This is seen from the mean values of all the items which are all above the criterion mean of 3.00. Standard deviation values ranging from 0.73 to 0.98 shows closeness in the responses of respondents.

\section{Discussion}

The finding of the study in table 1 reveals that poor parental guidance and supervision, poor motivation, lack of agricultural training in farming and fishing, poor reading accessories among others is home environmental issues leading to poor academic performance of students in Agricultural Science in Secondary Schools in Rivers State, Nigeria. 
This finding is in consonance with the views of Hoffman, Hutchinson and Reiss (2009) who posit that positive social environment has been linked to enhancing students' behaviour, academic achievement, and motivation. Similarly, the finding agrees with AziziYahaya(2010) who indicates that students' development is greatly influenced by their home environments. The finding according to table 2 indicated that poor supervision, poor training facilities, poor laboratories, inadequate trained teachers, lack of school pilot farms among others are the school environmental factors militating against the academic performance of students in Agricultural Science in secondary schools in Rivers State, Nigeria. This finding corroborates the views of Ekezie and Owo(2019) who reports that conducive school climate and classrooms that are well-equipped with modern teaching and learning facilities as well as adequate number of trained teachers will help enhance the development of student's cognitive, affective and psychomotor skills leading to excellent academic performance. Similarly, this finding shares a page with Brookover and Lezotte (1979) who stress that school goals of enhancing students' academic achievement will be possible if the teachers adopt appropriate educational and teaching strategies in managing and teaching the students. The finding according to table 3 revealed that increased supervision of schools' programmes, provision of pilot farms, engagement of more trained teachers as well as facility upgrade in schools among others are ways of improving the academic performance of students in Agricultural Science in secondary schools in Rivers State, Nigeria. This finding is in line with Willms (1992), who posits that schools having well-trained, committed and satisfied teachers produce students who attain academic excellence easily. Therefore, both home and school environments have great influence on students' performance at school and as such parents and teachers should be conscious of the fact that they need to give students maximum support in their academic pursuits if they want them to achieve academic excellence.

\section{Conclusion and Recommendations}

Agriculture is a very important sector in the Nigeria's economy and as such Agricultural Science as taught in secondary schools becomes crucial towards encouraging students' interests in food production, supply and processing. The performance of students in Agricultural Science which was found to be very poor was attributed to both the home and school environmental issues. Therefore, parents and teachers need to take the job of students' discipline and training seriously as it serves as an alternative to improved students' academic performance in Agricultural Science. Based on the findings of the study, the following recommendations were suggested: Government should provide functional school farms in all secondary schools in Rivers State. Government should provide modern books on Agricultural Science in secondary school libraries across Rivers State, Nigeria. Government should upgrade training facilities in secondary schools in Rivers State. Government should provide Agricultural tools and equipment in Agricultural Science Laboratories in secondary schools across Rivers State, Nigeria. The Rivers State Ministry of Education should ensure quality supervision of Agricultural Science instructions in Secondary Schools in Rivers State, Nigeria.

\section{Acknowledgements}

The researcher deeply acknowledges and appreciates the support of Mr. OWO, Offia Tugwell, a PhD scholar in the Department of Vocational and Technology Education, Rivers State University, Port Harcourt for the pragmatic and result-oriented roles he played towards ensuring the timely proof-reading of the manuscripts and offering of valuable suggestions crucial to the successful preparation and publication of the article. The author equally appreciates immensely the helpful comments and suggestions of friends and colleagues. Notable among these colleagues are Prof. P. C. Okwelle, Dr. N. S. Amadi, and Dr. A. U. Nnodim.

Author's Profile: Dr. Ekezie Anthony Imo Authur is an Associate Professor (Reader) of Vocational Agricultural Education, in the Department of Vocational and Technology Education, Rivers State University, Port Harcourt, Nigeria. His research interests span across general educational issues such as teaching strategies, academic achievements of students, supervision of educational programmes, skills acquisition, Youth empowerment approaches, employment generation in TVET, among others. 
Table1: Home environmental issues affecting the academic performance of students in Agricultural Science in Rivers State, Nigeria.

\begin{tabular}{|l|l|c|l|l|}
\hline S/N & Item Statement & $\bar{X}_{1}$ & SD & Decision \\
\hline 1 & Poor parental guidance and supervision. & 3.68 & 1.04 & Agree \\
\hline 2 & Lack of appropriate counseling on career choices. & 3.82 & 0.87 & Agree \\
\hline 3 & Poor parental motivation. & 4.09 & 0.90 & Agree \\
\hline 4 & Unavailability of computer at home. & 3.65 & 0.48 & Agree \\
\hline 5 & Poor electricity supply. & 3.58 & 0.84 & Agree \\
\hline 6 & Lack of reading tables and chairs. & 3.12 & 0.92 & Agree \\
\hline 7 & Lack of Agricultural training in fishing and farming. & 4.15 & 0.87 & Agree \\
\hline 8 & Poor awareness about sources of food supply for human consumption. & 3.92 & 0.85 & Agree \\
\hline & & & & \\
\hline 9 & Increased criminal activities in the society. & 2.29 & 0.89 & Disagree \\
\hline 10 & Lack of internet facilities for information gathering. & & & \\
\hline & & 3.88 & 1.03 & Agree \\
\hline 11 & Lack of reading materials on Agricultural Science at home. & & & \\
\hline
\end{tabular}

Table 2: School environmental issues affecting the academic performance of students in Agricultural Science in secondary schools in Rivers State, Nigeria

\begin{tabular}{|l|l|l|l|l|}
\hline S/N & Item Statement & $\overline{X_{1}}$ & SD & Decision \\
\hline 1 & Poor Agricultural Science supervision. & 3.98 & 0.76 & Agree \\
\hline 2 & Unavailability of school pilot farms in secondary schools. & 3.82 & 0.84 & Agree \\
\hline 3 & $\begin{array}{l}\text { Poor Agricultural Science Laboratories in Secondary } \\
\text { Schools. }\end{array}$ & 4.11 & 0.91 & Agree \\
\hline 4 & $\begin{array}{l}\text { Short supply of modern Agricultural materials in secondary } \\
\text { schools }\end{array}$ & 3.75 & 0.78 & Agree \\
\hline 5 & $\begin{array}{l}\text { Poor e-learning facilities such as computer, internet, e- } \\
\text { library. }\end{array}$ & 3.58 & 0.81 & Agree \\
\hline 6 & Poor classroom structures. & 2.82 & 0.97 & Agree \\
\hline 7 & $\begin{array}{l}\text { Inadequate agricultural training of students due to scarcity } \\
\text { of Agricultural Science teachers. }\end{array}$ & 4.15 & 0.87 & Agree \\
\hline 8 & Poor supply of Agricultural equipment and tools at schools. & 3.92 & 0.85 & Agree \\
\hline & \multicolumn{1}{|l}{} & 2.71 & 0.82 & Disagree \\
\hline 9 & Poor water supply in schools & 2.88 & 1.11 & Disagree \\
\hline 10 & Poor electricity supply in schools. & & & Agree \\
\hline & & 3.96 & 0.72 & \\
\hline 11 & Rigorous manual labour activities in secondary schools. & & & \\
\hline
\end{tabular}


Table 3: Ways of improving students' performance in Agricultural Science in secondary schools in Rivers State, Nigeria

\begin{tabular}{|c|c|c|c|c|}
\hline $\mathbf{S} / \mathbf{N}$ & Item Statement & $\overline{X_{1}}$ & SD & Decision \\
\hline 1 & Increased supervision of Agricultural Science lessons. & 4.12 & 0.84 & Agree \\
\hline 2 & Provision of pilot farms in all secondary schools in Rivers State, Nigeria. & 4.06 & 0.91 & Agree \\
\hline 3 & $\begin{array}{l}\text { Upgrading of facilities and equipment in Agricultural Science laboratories } \\
\text { across all secondary schools in Rivers State. }\end{array}$ & 4.22 & 0.78 & Agree \\
\hline 4 & $\begin{array}{l}\text { Mandatory practical Agricultural Science lessons in secondary schools in } \\
\text { Rivers State. }\end{array}$ & 3.75 & 0.92 & Agree \\
\hline 5 & $\begin{array}{l}\text { Provision of e-learning facilities such as computer, internet, e-library in } \\
\text { secondary schools in Rivers State. }\end{array}$ & 3.89 & 0.86 & Agree \\
\hline 6 & $\begin{array}{l}\text { Adequate provision of classroom structures in secondary schools in Rivers } \\
\text { State. }\end{array}$ & 3.82 & 0.98 & Agree \\
\hline 7 & Employment of more competent Agricultural Science teachers. & 4.04 & 0.73 & Agree \\
\hline 8 & $\begin{array}{l}\text { Adequate provision and maintenance of Agricultural equipment and tools in } \\
\text { secondary schools in Rivers State. }\end{array}$ & 3.92 & 0.88 & Agree \\
\hline
\end{tabular}

\section{References}

Aldridge, J. M., Mcchesney, K., \&Afari, E. (2017). Relationships between school climate, bullying and delinquent behaviours. Learning Environments Research. https://doi.org/10.1007/ s10984017-9249-6.

Arifin, R., Binti, M., Wahab, N. B. A., Teh, K. S. Bin, M., \&Otman, M. S. (2018). Influence of Social Environment on Student's Behaviour. International Journal of Academic Research in Business and Social Sciences, 8(7), 930939.

Azizi Y. (2010). The effects of various modes of absenteeism Problem in School on the academic performance of students in secondary schools. international journal of scientific and research publications, 12 (4).

Brookover, W.T. \& Lezotte, L.W. (1979). Changes in School Characteristics Coincident with Changes Students Achievement. A Paper Presented at the Institute of Research on Teaching, Michigan State University.

Ekezie, A. I. A. \&Owo, O. T. (2019). Assessment of the Capacity Building Needs of Agricultural Science Teachers for Innovative Instructional Delivery in Secondary Schools in Rivers State, Nigeria. Innovation of Vocational Technology Education, 15, (2) 43-57.

Esiobu, (2005). Gender Issues in Science and Technology Education Development. In: Science and Technology Education for Development, Uvowi, U.M.O. (Ed.). NERDC Press, Lagos pp:137-156.

Federal Government of Nigeria (2008). Directorate of Employment, Abuja, Nigeria.

Federal Ministry of Education (2004). National Policy on Education. Lagos: NERDC Press.

Hoffman, L.L., Hutchinson, C.J. \&Reiss, E. (2009). On improving school climate: Reducing reliance on rewards and punishment. International Journal of Whole Schooling, 5(1).

Oberle, S. L. \&Keeney, D.R. (1990). A Case for Agricultural Systems.

Olaitan, S.O. (1984). Agricultural education in the Tropics. Macmillan intermediate agriculture science. London, U.K: Macmillan Publishers Ltd.

Olamie W. (2012) Academic Performances article.

South African Qualification Authority (2003). Agricultural science as integrated Science [Online]. Available: http://www.saqa.org.za/ [Accessed].

Uzochi, B. C. (2011). The poor performance of students in examinations: Challenges and Remedies. A Journal of Federal. Ministry of Education, 13(1), 10-14.

Willms, J. D. (1992). Monitoring School Performance: A Guide for Educators. London: The Falmer Press.

Wright, B. (2012). Agriculture as a career. North Carolina. A and T state University. 